\section{UK inquiry into leukaemia cluster}

AN inquiry into allegations that radioactive discharges into the Irish Sea might have caused excess cancers in the coastal region of Cumbria was announced in the British Parliament last week by Mr Patrick Jenkin, Secretary of State for the Environment.

The allegations were made in a Yorkshire Television documentary (see Nature 3 November, p.5) which claimed to have found evidence of increased incidence of leukaemias and some other cancers near the coast of Cumbria, in the vicinity of a fuel reprocessing plant at Sellafield (formerly Windscale) run by British Nuclear Fuels Ltd. The programme also drew attention to radionuclides from the plant effluents that were found in household dust.

\section{Polish indictment}

THE act of indictment against the four Polish scholars - Jacek Kuron, Adam Michnik, Henryk Wujec and Zbigniew Romaszewski - who acted as "intellectual advisers" to Solidarity (see Nature 6 October, p.466) is causing considerable puzzlement in Warsaw legal circles. One eminent lawyer reportedly observed that it is unclear whether the authorities wish to sentence them to a term of imprisonment or put up a monument to them.

Among other activities, carried out within the framework of the Social SelfDefence Committee "KOR" (the forerunner of Solidarity), the four are charged with "various activities and public campaigns contrary to the existing legal order"' in pursuance of the aims of "'a struggle against reprisals undertaken on political, ideological denominational and racial grounds, and bringing help to people persecuted on these grounds; exposing violations of legality and helping the victims thereof; and providing support and defence for any social initiative designed to further respect for human and civic rights".

The long-term aim of the group is defined as "parliamentary democracy", by which, the indictment says, was meant a system based on a "widespread movement of 'self-governments' independent of the Party and the State authorities", to be extended in the first instance to state employees, agricultural producers, students, scientists and those employed in cultural work, and territorial units. This aim, the indictment said, was tantamount to attempting to overthrow the system.

In support of these aims, the group is accussed of circulating unofficial newspapers, organizing steering committees for a future independent trade union movement, setting up “'Students' Solidarity Committees" in the university and sponsoring the unofficial "Flying University".

Vera Rich
The government's review of the evidence is to be carried out by Sir Douglas Black, a former president of the Royal College of Physicians, who will be working in collaboration with health officers in the region. The fact of a local increased cancer incidence appears not to be in dispute: it is the interpretation of that fact that has caused controversy. The village of Seascale, named in the programme as having an increased incidence of childhood leukaemia, has rapidly expanded its population in recent years, and the Yorkshire team has not divulged the details of calculations purporting to show that the incidence is very unexpectedly high.

The difficulty of interpretation is illustrated by the observation that cancer incidence over a large area of Cumbria in the 1970s was significantly less than expected. Dr Peter Tiplady, community health adviser to the West Cumbrian Health Authority, is working on a breakdown of cancer statistics by towns and villages, and only then will it be possible to see whether Seascale is an isolated phenomenon. Cancer "clusters" have only recently become a focus of interest for epidemiologists. The theory necessary to estimate their significance is being investigated by the National Radiation Protection Board (NRPB) in conjunction with epidemiologists at the University of Oxford.

BNFL has stressed that dosage to individuals is thought to be ten to one hundred times less than would be necessary to

\section{Energy conservation

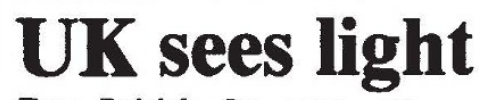

THE British Government's promised Energy Efficiency Office was launched with a flourish last week. Displaying the sort of evangelical zeal that cabinet ministers normally reserve for election times, Mr Peter Walker, Secretary of State for Energy, announced a "national crusade" to save money by promoting the more efficient use of energy. He aims to save onefifth of the $£ 100$ million that Britain spends daily on energy, and promises that "the campaign will not end until we have succeeded".

The Energy Efficiency Office is headed by $\mathrm{Mr}$ Bill McIntyre, who has worked in the oil industry and has previous departmental experience in conservation programmes. In its first year of operation, the of fice will have a budget of some $£ 15$ million, a 35 per cent increase on last year's conservation expenditure. The publicity campaign will cost $£ 3$ million, less than the "Save it" campaign that was promoted in the 1970 s, but officials hope that Mr Walker's personal commitment will make up for that. Ministers will be visiting more than 40 account for the Seascale leukaemia figures. The programme suggested that household dust might constitute an exposure route that has not been considered, but NRPB is convinced that ingestion and inhalation of household dust are insignificant dose routes. It has found airborne radioactivity in the region to be unimportant from the viewpoint of radiological protection.

BNFL has complained to the Independent Broadcasting Authority about the research techniques used by the Yorkshire Television team (which allegedly included improper approaches to individuals) and will also be lodging a complaint about "one-sided advance publicity". Highlights of the programme were given prominence in most newspapers in Britain before it was broadcast, and BNFL is annoyed that no other possible cause of the alleged cluster was mentioned.

One allegation in the programme that has particularly infuriated BNFL is the suggestion that radiation doses from its plant have been increasing. In fact, the company says, doses have decreased substantially in recent years and will be reduced further when an ion exchange effluent treatment plant is completed next year. Dosage to critical groups exceeded target recommendations for prolonged exposure of the International Committee on Radiological Protection (although not its dose limits) in 1981 and before, and the authorizing government departments have been "encouraging" BNFL to reduce its discharge levels. Draft authorizations now being considered will reduce discharges to one thirtieth of the present authorized level. The cost will be about $£ 80$ million.

Tim Beardsley

towns with exhibitions advising consumers on how to reduce waste, and chairmen of electricity, gas and coal boards have pledged their support. The campaign is aimed at both industry and the domestic consumer.

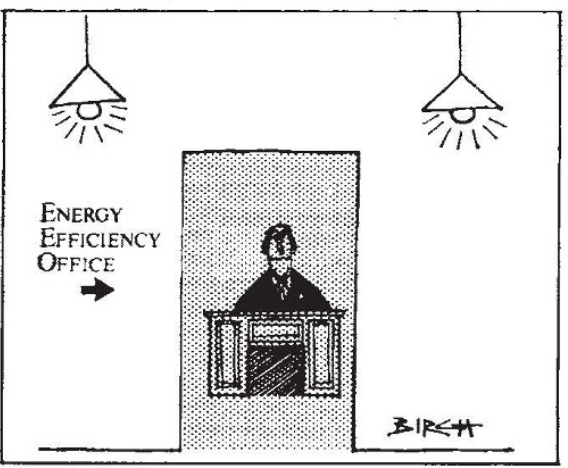

The government's declared strategy on energy conservation is that "realistic pricing" should be the main spur to efficiency, although even Mr Walker's predecessor, Mr Nigel Lawson, recognized that there is a place for government encouragement. There is a common feeling that government incentives have recently been haphazard and largely ineffective. Now, Mr Walker, a notorious cabinet "wet", seems keen to make amends.

Tim Beardsley 